$46(114)$

SS7-4

\title{
仙䬨排尿反射回路の可塑性理論による脊檤損傷に対する 新しい電気刺激療法の可能性
}

山梨医科大学 医学部 泌尿器科

荒木勇雄

哺乳動物の新生期における排尿は、陰部神経を求心路とし仙䯣副交感神経核を排尿中枢とする幼弱型の脊髄(会陰一膀 胱)反射によって担われている。しかし生後 3 週目を境として、骨盤神経を求心路とし橋を排尿中枢とする成熟型の脊䯣 一脸幹反射に取って代わられる。一方、ヒトを含めた成熟動物において、脊頜損傷によって上位中枢との伝達路が遮断さ れると、橋排尿中枢を介した成熟型の排尿反射は消失し、上述した幼弱型の脊娟排尿反射が再出現することも知られてい る。上記排尿反射は両者ともに、排尿筋の収縮と尿道括約笳の弛緩が同期する協調型の排尿反射である。しかしながら通 常、脊䯣損傷後に優位に出現してくる脊檤排尿反射は、排尿筋と尿道括約笳の作用が協調しない骨盤神経を求心路とする 非協調型の脊䯣排尿反射（膀胱一膀胱反射）であり、このことによって重篤な排尿障害が引き起こされることとなる。

基礎研究分野においても、神経回路の可塑性は中心的な課題であり、神経筋接合部・海馬・視覚野を中心に活発な研究 がなされている。神経回路の形態的可塑性の基礎的メカニズムとして、神経シナプスにおける長期增強（LTP）・長期抑 制 (LTD) と呼ばれるシナプス伝達効率の長期にわたる可塑性との関連が注目されている。これらの形態的・機能的可塑 性は、ともに神経活動に依存しており、神経経路を電気刺激することによりコントロールすることが可能である。

動物実験により実証された春䯣損傷時におこる仙髄排尿反射中枢における神経回路網の可塑性においても、同様のメカ ニズムが働いていると考えられる。したがって、脊䯣損傷後早期より、陰部神経知覚領域を電気刺激することにより、通 常なら優位に出現する骨盤神経を求心路とする非協調型の脊䯣排尿 (膀胱一膀胼) 反射に代うって、陰部神経を求心路と する協調型の脊檤排尿 (会陰一膀胱) 反射を強化確立することが可能であると考えられる。本治療法の概念は、障害の固 定した慢性期にみられる非協調型の異常排尿反射に対して対症的に施される従来の治療法とは根本的に異なる。

\section{SS7-5}

\section{電気刺激療法、磁気刺激療法の臨床と作用機序}

獨協医科大学 泌尿器科

山西友典, 安田耕作, 吉田謙一郎

過活動性膀脱に対する電気刺激療法の有効性は古くから報告がる。電気刺激療法は、体外あるいは体内電極を用いる方法、 また短期あるいは持続的に行う方法に分けられる。現在用いられる方法としては、体外電極を用いた短期的刺激法として、 家庭で行える小型の刺激装置を用いた骨盤底電気刺激や，干涉低周波療法があり、体内電極を使用した持続的刺激法として、 仙骨神経刺激法がある。骨盤底電気刺激装置の刺激電極としては、肍門電極、㓐電極, また陰茎などの皮唐を刺激する表面 電極がある。骨盤底電気刺激療法の過活動性膀胱に対する効果は、治癒 30-50\%、改善 60-70\% と報告され、dummy 装置 を使用した二重盲検試験によりその有効性も裹付けられた。また持ち越し効果 (carry over effect)や長期持続効果も報告さ れた。過活動膀胱に対する電気刺激療法の機序は、骨盤神経（副交感神経）遠心性神経の抑制反射あるいは下腹神経（交感 神経)の刺激により、排尿筋の収縮が抑制されるためと考えられている。排尿筋抑制の刺激条件としては、低周波数 (5一 10 $\mathrm{Hz}$ )が良いとされ、腹圧性尿失禁の場合と同様に、耐えうる最大刺激で、1 日 2 回行うのが望ましいとされている。低周波 数であるため、筋疲労は問題にならず、刺激は持続的に行ってよい。骨盤底電気刺激療法の持ち越し効果や長期持続効果の 機序は、先述の骨盤神経の抑制や下腹神経の刺激以外に、低周波数の陰部神経の刺激が、春䯣の interneuron を刺激し、 opioid, glycine, GABA などの抑制性神経伝達物質を放出したり、 $\beta$ 受容体を刺激するために、排尿筋の過活動が抑制される と考えられている。干涉低周波の原理は、皮周電気抵抗の低い 2 種の中周波電流 (約 $4000 \mathrm{~Hz}$ )を通じ、これら中周波電流が 体内で交差することによってうなり様に発生する干涉波 (低周波)により体内深部にある対象器官を刺激することである。 磁気刺激療法は、Barker らにより開発された非侵站的神経刺激療法で、刺激原理は電気刺激と同じであり、排尿筋反射が抑 制されることが報告されたが、従来の装置は、コイルの過熱のために、数秒間の刺激しかできなかった。最近になり、過活 動性膀胱による尿失禁の治療が可能な連続刺激式磁気刺激装置が開発され、その有効性、安全性が報告されるようになった。 